\title{
KEDUDUKAN LEMBAGA MEDIASI PERBANKAN SEBAGAI PILIHAN PENYELESAIAN SENGKETA ANTARA BANK DAN NASABAH PERBANKAN INDONESIA
}

\author{
Kadek Agus Sudiarawan (1) \\ Fakultas Hukum Universitas Udayana, Denpasar, Bali
}

\begin{abstract}
This research is aimed identifying the position of banking institutions as a choice of mediation dispute resolution between bank and customers banking of Indonesia as well as to find out the factors restricting and the cause of the weak level of the banking dispute resolution through mediation is associated with the introduction of PBI No. 8/5/PBI 2006 and PBI No. 10/1/PBI in 2008 about banking mediation. Types of research used in this paper included the normative legal research which put the law as a norm building system. This research uses secondary data where all of these data are analyzed using the qualitative methods. The report of this study is presented in a descriptive analysis. The results of the research indicated position of the institution of mediation as a form of banking is a real double protection for customers of banking Indonesia. As for restricting factors and causes of weak levels of dispute resolution through banking mediation include: yet the formation of independent banking mediation agencies banking, filing a dispute settlement arrangements are still concentrated in Bank Indonesia Jakarta, related publication duty setting the existence of institutions banking mediation without provisions supported sanctions, weak setting regarding the appointment and terms of the mediator, weak implementation arrangements and the peace agreement as well as the results of the pouring is not strictly speaking arrangements regarding sanctions against parties that do not comply with the mediation agreement banking.

Keywords: Banking, Alternative Dispute Resolution, Bank Indonesia Regulation on Banking Mediation.
\end{abstract}

Tujuan penelitian ini adalah untuk mengetahui kedudukan lembaga mediasi perbankan sebagai pilihan penyelesaian sengketa antara bank dan nasabah perbankan Indonesia serta untuk mengetahui faktor penghambat dan penyebab lemahnya tingkat penyelesaian sengketa perbankan melalui mediasi dikaitkan dengan berlakunya PBI No.8/5/PBI Tahun 2006 dan PBI No.10/1/PBI Tahun 2008 tentang Mediasi Perbankan.Jenis Penelitian yang digunakan dalam tulisan ini termasuk ke dalam penelitian hukum normatif yang meletakan hukum sebagai sebuah bangunan sistem norma. Data yang digunakan dalam penelitian ini adalah data sekunder. Seluruh data yang terkumpul dianalisis dengan menggunakan metode kualitatif. Hasil penelitian ini disajikan dalam suatu laporan yang bersifat diskriptif analisis. Hasil penelitian menunjukkan kedudukan lembaga mediasi perbankan adalah sebagai wujud nyata perlindungan ganda bagi nasabah perbankan Indonesia. Adapun faktor penghambat dan penyebab lemahnya tingkat penyelesaian sengketa perbankan melalui mediasi perbankan ialah meliputi : belum terbentuknya lembaga mediasi perbankan independen, pengaturan pengajuan penyelesaian sengketa yang masih terpusat di Bank Indonesia Jakarta, pengaturan kewajiban publikasi terkait keberadaan lembaga mediasi perbankan tanpa didukung ketentuan sanksi, lemahnya 
pengaturan mengenai penunjukan dan syarat-syarat mediator, lemahnya pengaturan pelaksanaan dan penuangan hasil kesepakatan perdamaian serta tidak tegasnya pengaturan mengenai sanksi terhadap pihak yang tidak mematuhi isi kesepakatan mediasi perbankan.

Kata Kunci : Perbankan, Alternatif Penyelesaian Sengketa, Peraturan Bank Indonesia Tentang Mediasi Perbankan

\subsection{Pendahulan}

Ketentuan Pasal 1 angka 1 Undang-Undang No. 10 Tahun 1998 tentang Perbankan (UU Perbankan) memberikan pengertian Perbankan sebagai segala sesuatu yang menyangkut tentang bank, mencakup kelembagaan, kegiatan usaha, serta cara dan proses dalam melaksanakan kegiatan usahanya. Sementara Bank berdasar ketentuan Pasal 1 angka 2 UU Perbankan diartikan sebagai badan usaha yang menghimpun dana dari masyarakat dalam bentuk simpanan dan menyalurkannya kepada masyarakat dalam bentuk kredit dan atau bentuk-bentuk lainnya dalam rangka meningkatkan taraf hidup rakyat banyak. Secara khusus terkait fungsi, bank dikenal sebagai financial intermediary institution, dimana bank diposisikan sebagai lembaga yang memiliki dua peranan penting yaitu sebagai lembaga penyimpan dana masyarakat dan sebagai lembaga penyedia dana bagi masyarakat dan atau dunia usaha. Hal ini menegaskan bahwa perbankan memiliki fungsi penting dalam perekonomian negara. ${ }^{1}$

Dalam dunia perbankan, nasabah merupakan konsumen dari pelayanan jasa perbankan. Kedudukan nasabah dalam hubungannya dengan pelayanan jasa perbankan, berada pada dua posisi yang dapat bergantian sesuai dengan sisi mana mereka berada. ${ }^{2}$ Hubungan antara bank dengan nasabahnya adalah hubungan yang bersifat keperdataan. Pihak nasabah merupakan unsur yang sangat berperan sekali, mati hidupnya dunia perbankan bersandar kepada kepercayaan dari pihak masyarakat atau nasabah.

Fungsi lembaga perbankan sebagai perantara pihak-pihak yang memiliki kelebihan dana membawa konsekuensi pada timbulnya interaksi yang intensif antara bank sebagai pelaku usaha dengan nasabah sebagai konsumen pengguna jasa perbankan. Dalam interaksi antara bank dengan

1 Burhanuddin Abdullah, 2006, Jalan Menuju Stabilitas Mencapai Pembangunan Ekonomi Berkelanjutan, Pustaka LP3ES Indonesia, Jakarta, hal.203

${ }^{2}$ Muhammad Djumhana, 2003, Hukum Perbankan di Indonesia, PT Citra, Bandung, hal.282 
nasabahnya pada setiap masalah yang terjadi dapat menurunkan kualitas bank tersebut dalam hubungannya dengan kepercayaan masyarakat.

Perlindungan konsumen perbankan merupakan salah satu permasalahan yang sampai saat ini belum mendapatkan tempat yang baik dalam Sistem Hukum Perbankan Indonesia. Diangkatnya masalah perlindungan konsumen sebagai salah satu pilar utama dalam Arsitektur Perbankan Indonesia (API), merupakan bukti upaya yang menunjukkan besarnya komitmen Bank Indonesia (BI) dan perbankan untuk menempatkan konsumen jasa perbankan memiliki posisi yang sejajar dengan bank. API merupakan suatu kerangka dasar sistem perbankan Indonesia yang terdiri dari enam pilar, bersifat menyeluruh dan memberikan arah, bentuk dan tatanan pada industri perbankan untuk rentang waktu lima sampai sepuluh tahun ke depan.

Enam pilar dalam Arsitektur Perbankan Indonesia meliputi :

1. Struktur perbankan yang sehat

2. Sistem pengaturan yang efektif

3. Sistem pengawasan yang independen dan efektif

4. Industri perbankan yang kuat

5. Infrastruktur pendukung yang mencukupi

6. Perlindungan Konsumen

Upaya perlindungan nasabah dalam Pilar ke VI API sendiri kemudian dituangkan dalam aspek yang terkait satu sama lain dan secara bersamasama akan dapat meningkatkan perlindungan dan pemberdayaan hak-hak nasabah. Empat aspek tersebut meliputi :

1. Penyusunan standar mekanisme pengaduan nasabah

2. Pembentukan lembaga mediasi perbankan

3. Penyusunan standar transparansi informasi produk

4. Peningkatan edukasi untuk nasabah

Regulasi-regulasi dalam bidang perbankan yang terkait langsung dengan upaya perlindungan nasabah bank diantaranya meliputi Peraturan Bank Indonesia (PBI) No. 7/6/PBI/2005 tanggal 20 Januari 2005 tentang "Transparansi Informasi Produk Bank dan Penggunaan Data Pribadi Nasabah" dan PBI No. 7/7/PBI/2005 tanggal 20 Januari 2005 tentang "Penyelesaian Pengaduan Nasabah" dan PBI No.8/5/PBI/2006 tanggal 30 Januari 2006 tentang "Mediasi Perbankan". 
Sejatinya dalam suatu sistem hukum perbankan, perlindungan hukum bagi nasabah bank seharusnya sudah dilakukan pada tahap pra-perjanjian sampai dengan pelaksanaan perjanjian. Ketika hubungan hukum antara bank dan nasabah mulai tercipta, maka sejak itu terbuka kemungkinan sengketa antar para pihak. Penyelesaian sengketa tersebut dapat dilakukan melalui proses litigasi dan non-litigasi. Pada perkembangan kondisi perbankan hari ini, penyelesaian sengketa melalui jalur non-litigasi merupakan suatu tawaran alternatif menarik yang dapat ditempuh oleh bank dan nasabah dalam menyelesaikan masalah-masalah perbankan yang seringkali dihadapi.

Dalam merespon permasalah-permasalahan perbankan yang seringkali terjadi antara nasabah dan bank, pemerintah melalui Bank Indonesia kemudian mengeluarkan kebijakan Peraturan Bank Indonesia Nomor 7/7/PBI/2005 tentang Penyelesaian Pengaduan Nasabah. Ketika dalam pelaksanaanya dirasa masih kurang dapat memuaskan nasabah, Bank Indonesia kemudian merespon dengan mengeluarkan Peraturan Bank Indonesia Nomor 8/5/PBI/2006 Jo Peraturan Bank Indonesia Nomor 10/1/PBI/2008 Tentang Perubahan Atas Peraturan Bank Indonesia Nomor 8/5/PBI/2006 tentang Mediasi Perbankan (PBI Mediasi Perbankan) sebagai salah satu bentuk tawaran alternatif yang dapat digunakan dalam menyelesaikan sengketa perbankan di Indonesia.

Data yang dihimpun Bank Indonesia kemudian menunjukkan bahwa jumlah penyelesaian sengketa melalui mediasi perbankan masih relatif minim. Hal ini menunjukkan masih lemahnya tingkat penyelesaian kasus atau sengketa perbankan melalui Alternatif Penyelesaian Sengketa di Indonesia di tengah maraknya kasus atau sengketa yang terjadi di dunia perbankan Indonesia saat ini. ${ }^{3}$

Secara teknis, apabila pengaduan nasabah tidak diselesaikan dengan baik oleh bank sejatinya akan berpotensi menjadi perselisihan atau sengketa yang berlarut-larut dan cenderung akan merugikan pihak perbankan. Ketidakpuasan tersebut sering terjadi dikarenakan tidak terpenuhinya tuntutan nasabah bank baik seluruhnya maupun sebagian sehingga berpotensi menimbulkan sengketa lebih rumit antara nasabah

${ }^{3}$ Bank Indonesia, Data Bank Indonesia terhadap Kasus-Kasus Perbankan melalui Mediasi, tercantum dalam URL : http://www.bi.go.id, diakses tgl 15 Maret 2016 
dengan bank. Dari permasalahan ini kehadiran lembaga mediasi perbankan dinilai sangat penting, dikarenakan selain penyelesaian melalui jalur ini dirasa lebih efektif dan lebih efisien bagi para pihak yang bersengketa, perbankan juga merupakan lembaga yang sangat mengandalkan kepercayaan dari masyarakat luas. Masyarakat mengandalkan jasa bank dilandasi rasa kepercayaan. Oleh karena itu, kepercayaan dari masyarakat harus tetap terjaga.

Berangkat dari latar belakang tersebut penulis tertarik untuk menganalisis lebih dalam terkait dengan : "Kedudukan Lembaga Mediasi Perbankan Sebagai Pilihan Penyelesaian Sengketa Antara Bank dan Nasabah Perbankan Indonesia". Adapun beberapa permasalahan yang akan dianalisis dalam tulisan ini meliputi :

1. Bagaimakah kedudukan lembaga mediasi perbankan sebagai pilihan penyelesaian sengketa antara Bank dengan Nasabah ditinjau menurut Sistem Hukum Perbankan Indonesia?

2. Apakah yang menjadi faktor penghambat dan penyebab lemahnya tingkat penyelesaian sengketa perbankan melalui mediasi dikaitkan dengan berlakunya PBI No.8/5/PBI Tahun 2006 dan PBI No.10/1/PBI Tahun 2008 tentang Mediasi Perbankan?

\section{PEMBAHASAN}

\subsection{Kedudukan Lembaga Mediasi Sebagai Pilihan Penyelesaian}

\section{Sengketa}

\section{Antara Bank dan Nasabah Dalam Sistem Hukum Perbankan Indonesia}

Secara umum Mediasi Perbankan merupakan salah satu alternatif penyelesaian sengketa yang ditawarkan oleh pihak bank dalam upaya menyelesaikan perselisihan atau sengketa yang terjadi antara bank dan nasabah. Kehadiran jalur mediasi perbankan pada intinya adalah untuk dapat menjembatani dan/atau memediasi antara kepentingan bank dan nasabah sehingga dapat menyelesaikan problem hukum yang terjadi dengan baik, terkhusus untuk sengketasengketa perbankan yang akhir-akhir ini begitu marak di dunia perbankan Indonesia. 
Proses mediasi perbankan sesuai dengan sistem hukum perbankan Indonesia merupakan sarana tindak lanjut atau keberlanjutan dari tahapan sebelumnya, yaitu pengaduan nasabah apabila nasabah merasa tidak puas atas penanganan dan penyelesaian yang diberikan atau dilakukan oleh pihak bank. Dimana kita ketahui bersama, dalam pelaksanaan kegiatan usaha perbankan seringkali hak-hak nasabah tidak dapat terlaksana dengan baik sehingga seringkali menimbulkan permasalahan-permasalahan antara nasabah dan bank yang ditunjukkan dengan munculnya pengaduan nasabah.

Pada PBI No. 7/7/PBI/2005 jo PBI No.10/10/PBI/2008 tentang Penyelesaian Pengaduan Nasabah, Bank Indonesia mewajibkan seluruh bank untuk menyelesaikan setiap pengaduan nasabah yang terkait dengan adanya potensi kerugian finasial pada sisi nasabah. Pada prinsipnya PBI ini mengatur mengenai bank tidak diperkenankan menolak setiap pengaduan yang diajukan secara lisan maupun tertulis. Tahapan inilah yang kemudian menjadi tahapan awal dalam mekanisme penyelesaian sengketa perbankan sesuai dengan Peraturan Bank Indonesia.

Dalam tahapan penyelesaian sengketa perbankan selanjutnya, apabila pengaduan nasabah tidak diselesaikan dengan baik oleh bank, maka berpotensi menjadi perselisihan berlanjut atau sengketa antara nasabah dengan pihak bank cenderung berlarut-larut. Hal ini antara lain ditunjukkan dengan cukup banyaknya keluhan-keluhan yang tersebar pada masyarakat melalui berbagai media tersebut dapat menurunkan reputasi atau citra positif suatu bank di mata masyarakat dan sangat berpotensi menurunkan tingkat kepercayaan masyarakat terhadap lembaga perbankan tersebut. Dimana untuk mengurangi publikasi negatif terhadap operasional bank dan menjamin terselenggarakanya mekanisme penyelesaian pengaduan nasabah secara efektif dalam jangka waktu yang memadai, maka Bank Indonesia menetapkan standar minimum mekanisme penyelesaian pengaduan nasabah melalui PBI No.7/6/PBI/2005 tentang Transparansi Informasi Produk Bank dan Penggunaan Data Pribadi Nasabah dan PBI No.7/7/PBI/2005 tentang Penyelesaian Pengaduan 
Nasabah yang wajib dilaksanakan diseluruh bank.

Penentuan kebijakan Bank Indonesia melalui kebijakan pembentukan lembaga mediasi perbankan diatas merupakan bagian dari Arsitektur Perbankan Indonesia yang harus terus disempurnakan agar semakin baik. Meskipun banyak kalangan masih pro-kontra seputar payung hukum terhadap mediasi perbankan. Adapun latar belakang utama dikeluarkanya Peraturan Bank Indonesia yang menjadi landasan utama dilaksanakannya Mediasi Perbankan ialah terdapat beberapa hal yang diantaranya meliputi :

- Untuk membantu menjaga reputasi bank sebagai lembaga intermediasi, karena penyelesaian pengaduan nasabah oleh bank ternyata tidak selalu dapat memuaskan nasabah dan dapat berpotensi menimbulkan sengketa di bidang perbankan antara nasabah dengan bank yang jika dibiarkan akan dapat merugikan nasabah dan meningkatkan resiko reputasi bagi bank.

- Untuk memberikan alternatif penyelesaian sengketa kepada nasabah, khususnya bagi nasabah kecil dan usaha mikro dan kecil (UMK), berhubung nasabah UMK tidak mudah mendapatkan akses hukum dan dana untuk menyelesaikan sengketanya dengan bank melalui lembaga arbitrase atau peradilan dan merupakan bagian terbesar dari nasabah bank secara keseluruhan.

- Penyelesaian sengketa nasabah dengan bank bagi nasabah UMK perlu diupayakan secara sederhana, murah, dan cepat, yaitu melalui penyelenggaraan mediasi perbankan, sehingga hak-hak nasabah dapat terjaga dan terpenuhi dengan baik.

- Mediasi merupakan cara atau sarana yang efektif bagi penyelesaian sengketa di bidang perbankan antara nasabah dan bank, karena kepentingan nasabah maupun reputasi bank dapat dijaga dan demikian pula dengan kepentingan dan hak-hak nasabah sebagai konsumen pengguna jasa perbankan dapat terlindungi. ${ }^{4}$

Adapun secara khusus keunggulan atau keuntungan adanya

${ }^{4}$ Rachmadi Usman, 2011. Penyelesaian Pengaduan Nasabah dan Mediasi Perbankan, Bandar Maju, Bandung. hal.197-198 
langkah mediasi atau lembaga mediasi sebagai pilihan penyelesaian permasalahan atau sengketa-sengketa perbankan menurut meliputi :

- Mediasi Perbankan mampu membantu mencarikan jalan keluar atau alternatif penyelesaian sengketa atas sengketa yang timbul di antara para pihak yang disepakati dan dapat diterima oleh para pihak yang bersengketa.

- Dalam proses Mediasi ditekankan bahwasanya yang hendak dicapai bukanlah mencari kebenaran dan atau dasar hukum yang diterapkan namun lebih kepada penyelesaian masalah secara tuntas tanpa meninggalkan luka diantara para pihak.

- Melalui proses mediasi diharapkan dapat dicapai terjalinnya komunikasi yang lebih baik di antara para pihak yang bersengketa.

- Menjadikan para pihak yang bersengketa dapat mendengar, memahami alasan, penjelasan, argumentasi, yang menjadi dasar pertimbangan pihak yang lain.

- Adanya pertemuan tatap muka, diharapkan dapat mengarungi rasa marah atau bermusuhan antara pihak yang satu dengan yang lain, yang dalam kontek ini antara pihak bank dan nasabah.

- Memahami kekurangan atau kelebihan masing-masing, dan hal ini diharapkan dapat mendekatkan cara pandang dari pihak-pihak yang bersengketa, menuju suatu kompromi yang dapat diterima para pihak.

Dalam konteks penyelesaian suatu sengketa perbankan, peranan lembaga mediasi sangatlah penting dalam upaya mencapai kesetaraan antara para pihak yang berada dalam konflik sehingga dapat menyelesaikan secara internal. ${ }^{5}$ Dalam penyelesaian sengketa melalui lembaga mediasi, yang menjadi fokus adalah kepentingan dari masing-masing pihak, sehingga pengambil keputusan adalah para pihak sendiri, mediator tidak berperan memutuskan.

Masa awal digulirkannya gagasan pembentukan lembaga mediasi perbankan ini sebagian kalangan perbankan memang memandang bahwa langkah pembentukan lembaga ini akan

5 Inosentius Samsul, 2009, Pengembangan Model Penyelesaian Sengketa Perbankan dalam Perpekstif Perlindungan Konsumen, dikutip dari Artikel dalam Buletin Hukum Perbankan dan Kebanksentralan, Jakarta : Direktur Hukum Bank Indonesia, hal.27-28 
memperberat posisi mereka. Padahal sejatinya adanya lembaga seperti ini justru akan memperkuat posisi perbankan di hadapan nasabah. Hal ini justru akan memperkuat daya saing perbankan. Keuntungan lainnya dalam penyelesaian sengketa melalui lembaga mediasi, para pihak biasanya mampu mencapai kesepakatan di antara mereka, sehingga manfaat mediasi dapat dirasakan, adapun beberapa keuntungan ataupun manfaat mediasi untuk menjadi penguat masyarakat dapat memilih dan mengunakan lembaga mediasi ini sebagai alternatif penyelesaian sengketa dalam konteks ini ialah meliputi :

- Mediasi dapat menyelesaikan sengketa dengan cepat, biaya murah dibandingkan dengan proses beracara dipengadilan atau melalui Arbitrase. Dalam proses mediasi tidak diperlukan gugatan ataupun biaya untuk mengajukan banding sehingga biayanya lebih murah.

- Mendorong terciptanya iklim yang kondusif bagi para pihak yang bersengketa tetap menjaga hubungan kerjasama mereka yang sempat terganggu akibat terjadinya persengketaan diantara mereka.

- Proses mediasi lebih bersifat informal dan menghasilkan putusan yang tidak memihak, berbeda dengan proses dipengadilan yang sifatnya kaku dan formal. ${ }^{6}$

Dewasa ini hampir semua negara mengembangkan berbagai jalan terobosan alternatif, karena kelemahan penyelesaian sengketa melalui ajudikasi yang mengakibatkan terkurasnya sumber daya, dana, waktu, pikiran dan tenaga, dan mulai mengedepankan pola-pola penyelesaian sengketa di luar pengadilan. ${ }^{7}$ Adapun tujuan khusus diselenggarakannya lembaga mediasi perbankan adalah untuk memaksa seluruh bank agar bersedia dan peduli dalam menyelesaikan seluruh sengketa terjadi dengan nasabah, termasuk nasabah kecil yang jika dibiarkan berlarut-larut dapat berpotensi meningkatkan risiko reputasi sebuah bank. Selain itu mediasi

${ }^{6}$ Muhammad Djumhana, op.cit, hal 164-166

7 Susanti Adi Nugroho, 2008, Proses Penyelesaian Sengketa Konsumen Ditinjau dari Hukum Acara serta Kendala Implementasinya,_Jakarta : Kencana, hal.13 
perbankan bertujuan untuk memberdayakan nasabah pada fase setelah nasabah memanfaatkan jasa atau produk bank. Dengan kata lain, terbitnya ketentuan mengenai mediasi pebankan dapat diterjemahkan sebagai upaya Bank Indonesia untuk memberdayakan nasabah melalui penambahan satu garda lagi, sehingga posisi nasabah akan lebih kuat karena mendapatkan proteksi ganda.

Dalam konteks kebijakan pengembangan perbankan nasional, keluarnya $\mathrm{PBI}$ Mediasi Perbankan merupakan wujud nyata dari Arsitektur Perbankan Indonesia (API) dalam memberikan perlindungan hukum kepada nasabah sebagai konsumen pengguna jasa perbankan serta sekaligus memberdayakan nasabah sebagai konsumen penggunan jasa perbankan, sehingga eksistensi dan esensi nasabah sebagai konsumen pengguna jasa perbankan juga setara dengan bank sebagai pelaku usaha penyedia jasa perbankan.

Sehingga dari berbagai analisis terhadap aturan hukum dan pandangan-pandangan diatas dapat ditarik sebuah simpulan bahwasanya hadirnya "Lembaga Mediasi" dalam dunia perbankan Indonesia merupakan suatu terobosan yang merupakan wujud nyata bentuk perlindungan ganda bagi nasabah perbankan Indonesia, dimana melalui lembaga mediasi perbankan diharapkan akan memberikan nilai positif, seperti diantaranya memberikan kepastian penyelesaian sengketa nasabah, terutama nasabah kecil dengan banknya, lembaga mediasi akan menjadi semacam watch dog karena perbankan tidak akan dapat santai-santai lagi untuk membiarkan sengketa dengan nasabahnya tanpa ada itikad baik untuk menyelesaikannya. Mekanisme penyelesaian sengketa melalui lembaga mediasi sangat memungkinkan dan menguntungkan bagi nasabah, terutama nasabah kecil untuk dapat mengadukan sengketanya yang tidak dapat diselesaikan secara bilateral dengan bank melalui prosedur pengaduan nasabah.

\subsection{Faktor penghambat dan penyebab lemahnya penyelesaian sengketa melalui mediasi perbankan}

Sesuai dengan data statistik Bank Indonesia terkait sengketasengketa yang diajukan penyelesaiannya melalui mediasi perbankan, 
didapat data bahwasanya sejak dibuka pada Januari 2006 mediasi perbankan disambut dengan positif oleh nasabah perbankan Indonesia. Hal ini terbukti dari antusiasme nasabah dalam mengadukan sengketa mereka ke mediasi perbankan. Data statistik tentang jumlah sengketa menunjukkan pada sejak bulan Januari 2006 hingga Desember 2006 jumlah pengaduan dan permohonan penyelesaian sengketa melalui mediasi Bank Indonesia tercatat

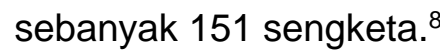

Kemudian pada tahun 2007 berdasarkan data Bank Indonesia, sepanjang 2007 Bank Indonesia telah menerima sebanyak 64.288 pengaduan. Dari jumlah itu 97,8 persen pengaduan adalah pengaduan nasabah di bidang sistem pembayaran. Sisanya, pengaduan di bidang penghimpunan dana, penyaluran dana, produk kerja sama dan produk lainnya. Dari seluruh pengaduan itu, permintaan penyelesaian dengan cara mediasi sebanyak 200 sengketa. Sampai akhir 2007, Bank Indonesia telah menyelesaikan 90 persen sengketa dan sisanya sedang dalam proses penyelesaian. ${ }^{9}$

Dalam perkembangan kemudian, penyelesaian sengketa melalui mediasi perbankan pada tahun 2008 hingga 2015 dari segi kuantitas pengajuan sengketa nasabah dengan bank telah mengalami peningkatan pesat. Data statistik Bank Indonesia menyebutkan, penanganan sengketa mediasi perbankan sejak Januari hingga Juni 2008 adalah 158 kasus. Dari jumlah tersebut sebanyak 89 kasus selesai tanpa mediasi, 60 kasus sedang diproses, 6 kasus diselesaikan oleh bank dan 3 kasus diselesaikan dengan mediasi perbankan. Dan hingga untuk triwulan tahun 2012 ini sudah terdapat 148 kasus perbankan, dan yang bisa dimediasi hanya 25 kasus, dan jika dihitung hingga Desember 2011 lalu terdapat 510 kasus perbankan yang terjadi di dunia perbankan Indonesia. Hal ini menunjukkan masih lemahnya tingkat penyelesaian kasus atau sengketa perbankan melalui Alternatif Penyelesaian Sengketa di

8 Bank Indonesia, 2012, Data Penyelesaian Sengketa Melalui Mediasi Perbankan oleh Bank Indonesia, hal.155, dikutip dari http://www.bi.go.id/web/id/, diakses pada 21 Maret 2016.

9 lbid, hal.156 
Indonesia di tengah maraknya kasus atau sengketa yang terjadi di dunia perbankan Indonesia. ${ }^{10}$

Berdasarkan uraian statistik diatas, dapat dianalisis bahwa terdapat beberapa faktor yang menjadi penyebab dan mempengaruhi masih lemahnya tingkat penyelesaian sengketa melalui mediasi perbankan di Indonesia yang antara lain meliputi beberapa hal utama seperti adanya beberapa ketentuan dalam Peraturan Bank Indonesia mengenai Mediasi Perbankan yang memiliki beberapa kelemahan. Hal ini dapat kita temukan seperti pada ketentuan Pasal 5 ayat (1) PBI Nomor 8/5/PBI/2006 jo PBI No.10/1/PBI/2008 tentang Mediasi Perbankan yang menyatakan bahwa : Bank Indonesia menunjuk mediator, namun tidak menjelaskan (selama belum dibentuk Lembaga Mediasi Independen) apakah mediator berasal dari intern Bank Indonesia atau staff dari Bank Indonesia ataupun mediator professional. Ayat (2) menyebutkan tentang syarat mediator yaitu mempunyai pengetahuan perbankan, keuangan atau hukum, tidak mempunyai kepentingan dengan para pihak dan tidak mempunyai kepentingan dengan para pihak dan tidak mempunyai hubungan darah maupun semenda dengan para pihak. Dari syarat-syarat tersebut, dapat diasumsikan bahwa mediator yang ditunjuk Bank Indonesia bisa berasal dari dalam Bank Indonesia atau internal Bank Indonesia ataupun dari luar Bank Indonesia, asalkan memenuhi syarat-syarat yang telah ditetapkan. Analisis terhadap ketentuan menurut pandangan penulis, selayaknya selain syarat yang telah dicantumkan tersebut hendaknya ditambahkan bahwa seorang mediator harus mempunyai sertifikat mediator. Adapun yang disebut dengan sertifikat mediator adalah dokumen yang menyatakan bahwa seseorang telah mengikuti pelatihan atau pendidikan mediasi yang dikeluarkan oleh lembaga yang diakreditasi oleh Mahkamah Agung.

Dalam praktek-praktek mediasi di pengadilan, ketidakberhasilan hakim berperan sebagai mediator banyak disebabkan oleh karena mereka tidak mendapatkan pelatihan mediator sehingga tidak menerapkan teknik dan strategi mediasi yang benar. Apabila Bank Indonesia tidak mensyaratkan adanya sertifikat mediator bagi para

\section{$10 \mathrm{lbid}$}


mediatornya, bukan tidak mungkin bahwa mediasi perbankan akan banyak mengalami kebuntuan, walaupun yang berperan sebagai mediator adalah ahli dalam bidang perbankan, hukum ataupun ekonomi. Pengetahuan substansi permasalahan yang disengketakan walaupun perlu untuk dimiliki oleh seorang mediator, namun tidak mutlak dibutuhkan. Hal ini disebabkan menurut praktek mediasi, mediator maupun para pihak diperkenankan untuk meminta bantuan ahli untuk dimintai pendapat atas sengketa yang sedang berlangsung.

Adapun nilai terpenting yang harus dimiliki oleh seorang mediator adalah kemampuan menganalisis dan keahlian menciptakan pendekatan pribadi. ${ }^{11}$ Pada dasarnya berhasil atau tidaknya suatu sengketa diselesaikan melalui mediasi sangat dipengaruhi oleh kemampuan mediator dalam menguasai dan menerapkan teknik mediasi serta kemampuan memanfaatkan tahapan-tahapan mediasi secara optimal untuk mengidentifikasi isu, menetapkan interest, dan menawarkan opsi penyelesaian sengketa. Dengan demikian, suatu proses mediasi akan mempunyai kualitas yang berbeda, tergantung pada kemampuan mediatornya.

Adapun kelemahan lainnya dari pelaksanaan mediasi perbankan adalah pada kekuatan eksekusinya (kaitanya dengan Pasal $13 \mathrm{PBI}$ Mediasi Perbankan tentang kewajiban Bank dalam pelaksanaan hasil kesepakatan dan penuangan dalam akta kesepakatan). Efektifitasnya sangat tergantung dari itikad baik para pihak menaati hasil kesepakatan tersebut. Apabila salah satu pihak tidak mau melaksanakan kesepakatan yang telah dicapai, tidak ada upaya hukum yang dapat dilakukan untuk memaksakannya dan tidak diatur pula tentang pendaftaran kesepakatan. Kelemahan ini telah diusahakan untuk diatasi oleh Peraturan Bank Indonesia tentang Mediasi Perbankan. Dimana, dalam hal ini Bank Indonesia diberikan kewenangan untuk menjatuhkan sanksi administratif (Pasal 16 angka $1 \mathrm{PBI}$ Mediasi Perbankan) kepada bank yang tidak mematuhi isi kesepakatan mediasi. Bentuk sanksi tersebut berupa teguran tertulis serta diperhitungkannya ketidakpatuhan itu dalam komponen penilaian

11 Suyud Margono, 2000, ADR dan Arbitrase Proses Pelembagaan dan Aspek Hukum, Jakarta : Ghalia Indonesia, hal.47 
tingkat kesehatan bank (Pasal 16 angka 2 PBI tentang Mediasi Perbankan). Pemberian sanksi oleh Bank Indonesia sebagai lembaga ekternal (ekternal authority) dapat dibenarkan demi efektifitasnya mediasi. Namun demikian, sanksi dari Bank Indonesia tersebut belum cukup maksimal untuk memberi perlindungan kepada nasabah. Sanksi dari Bank Indonesia tidak bersifat tegas dan memaksa agar bank melaksanakan kewajibannya, tetapi lebih kepada sanksi administratif dan sanksi sosial saja. Nasabah yang dirugikan tidak dapat menggunakan upaya hukum untuk mendapatkan ganti kerugian yang menjadi haknya.

Disamping itu $\mathrm{PBI}$ tentang Mediasi Perbankan tidak mengatur mengenai sanksi apabila nasabah tidak mau melaksanakan kesepakatan. Penentuan bahwa yuridiksi mediasi adalah sengketa antara nasabah dan bank yang disebabkan tidak dipenuhinya tuntutan finansial nasabah oleh bank, tidak menghilangkan kemungkinan bahwa dalam hasil kesepakatan mediasi juga terdapat kewajiban atau prestasi yang dibebankan kepada nasabah.

Analisis lebih dalam mengenai aturan mengenai PBI Mediasi Perbankan dan pandangan-pandangan dari elemen-elemen terkait dengan pelaksanaan mediasi perbankan memunculkan beberapa penghambat-penghambat yang seringkali ditemukan dalam pelaksanaan mediasi dalam penyelesaian-penyelesaian sengketa perbankan Indonesia. Faktor-faktor penghambat pelaksanaan mediasi perbankan sebagai alternatif penyelesaian sengketa perbankan Indonesia adalah meliputi beberapa hal, baik yang sifatnya substansial maupun dalam teknis pelaksanaannya dilapangan. Adapun secara khusus faktor penghambat utama dan seringkali dihadapi Bank Indonesia dalam pelaksanaan mediasi perbankan ialah meliputi :

- Penyelesaian sengketa dengan cara mediasi belum membudaya di kalangan masyarakat, termasuk bagi nasabah dan bank itu sendiri, sehingga sangat diperlukan sosialisasi dan pubikasi maksimal terkait keberadaan lembaga mediasi perbankan dan keunggulan-keunggulan penyelesaian sengketa melalui mediasi perbankan (Pasal 14 PBI Mediasi Perbankan). 
- Nasabah kurang memahami kasus posisi yang sebenarnya, nasabah juga tidak memberikan dokumen yang lengkap, serta tidak mencantumkan telepon yang bisa dihubungi untuk proses klarifikasi oleh Direktorat Investigasi dan Mediasi Perbankan Bank Indonesia. Hal-hal yang sifatnya teknis seringkali menjadi penghambat pelaksanaan mediasi perbankan dapat berlangsung secara lebih praktis dan efisien.

- Bank Indonesia kesulitan untuk menghubungi pejabat di bank yang berkompeten untuk dipanggil dan menjalani proses mediasi. Seringkali, utusan yang dikirim oleh bank tidak memiliki kewenangan memutus. Hal ini berakibat proses mediasi tidak dapat berjalan sebagaimana mestinya sebab staff tidak dapat menawarkan opsi-opsi atau memberikan alternatif penyelesaian masalah. Sehingga proses mediasi tidak berjalan efektif dan membutuhkan waktu lama.

- Ketentuan yang menyatakan bahwa semua permohonan mediasi harus ditujukan kepada Direktorat Investigasi dan Mediasi Perbankan di Kantor Pusat Bank Indonesia di Jakarta (Pasal 15 PBI Mediasi Perbankan), dipercaya sebagai faktor penghambat penyelesaian sengketa yang efektif.

- Segi kepraktisan dan biaya pelaksanan mediasi perbankan. Meskipun proses mediasi dapat dilakukan di kantor Bank Indonesia yang paling dekat dengan domisili nasabah atau bank, mediator tetaplah dari kantor Bank Indonesia Jakarta. Hal ini berimbas pada besarnya biaya yang harus dikeluarkan Bank Indonesia dalam menjalankan fungsi mediasi.

Selain itu Fakta dilapangan juga menunjukkan bahwa masih banyak pejabat bank yang belum mengetahui ketentuan mediasi perbankan. Akibatnya proses penyelesaian sengketa tidak dapat menghasilkan penyelesaian yang optimal atau bahkan mengalami kegagalan. Seringkali proses mediasi berujung pada hasil "sepakat atau tidak sepakat" hanya karena terlalu kaku terhadap aturan batas waktu penyelesaian sengketa.

Selain pandangan-pandangan diatas menurut data Bank Indonesia bahwa mediasi perbankan sendiri sebenarnya belum dikenal 
luas oleh nasabah. Masih banyak nasabah yang tidak mengetahui keberadaannya meskipun Bank Indonesia mewajibkan tiap bank memberikan informasi tentang hak-hak nasabah termasuk mediasi. Minimnya informasi dari bank ini menyebabkan sebagian nasabah berhenti pada tahap pengaduan nasabah saja, tanpa melanjutkan proses ke mediasi meskipun mereka tidak puas dengan penyelesaian sengketa yang dimilikinya. Hal ini membuktikan bahwasanya apa yang diamanatkan dalam ketentuan Pasal 14 PBI Mediasi Perbankan dan Surat Edaran Bank Indonesia Nomor 8/14/DPNP yang menentukan kewajiban publikasi oleh bank terkait adanya sarana mediasi perbankan dan kewajiban publikasi melalui media-media publikasi sebagaimana ditentukan surat edaran tersebut belum dilaksanakan secara maksimal.

Kelemahan dan beberapa faktor penghambat inilah yang kemudian membuat pelaksanaan mediasi perbankan sebagai alternatif penyelesaian sengketa antara bank dan nasabah masih kurang maksimal pelaksanaannya, sehingga diperlukan suatu metode-metode pendukung untuk memperkuat pelaksanaan mediasi sebagai pilihan yang tepat, yang apabila dibandingkan dengan bentuk penyelesaian lainnya, mediasi perbankan memiliki begitu banyak keunggulan karakteristik yang akan memberikan banyak keuntungan bagi nasabah dan bank.

\section{Penutup}

\subsection{Kesimpulan}

Berdasarkan uraian permasalahan yang telah dibahas, maka dapat ditarik beberaapa kesimpulan sebagai berikut :

1. Kedudukan lembaga mediasi sebagai pilihan penyelesaian sengketa antara bank dan nasabah adalah sebagai wujud nyata perlindungan ganda bagi nasabah perbankan, selain itu penyelesaian sengketa melalui lembaga mediasi perbankan juga mampu menjaga reputasi bank sebagai lembaga intermediasi dan mampu memberikan alternatif penyelesaian sengketa kepada nasabah, khususnya kepada nasabah kecil dengan mekanisme yang lebih sederhana, cepat dan biaya ringan. 
2. Faktor penghambat dan penyebab lemahnya tingkat penyelesaian sengketa perbankan dikaitkan dengan berlakunya PBI No.8/5/PBI Tahun 2006 dan PBI No.10/1/PBI Tahun 2008 Tentang Mediasi Perbankan meliputi :

- Penghambat: belum terbentuknya lembaga mediasi perbankan independen, pengaturan pengajuan penyelesaian sengketa yang masih terpusat di Bank Indonesia Jakarta, pengaturan kewajiban publikasi terkait keberadaan lembaga mediasi perbankan tanpa didukung ketentuan sanksi yang tegas bagi bank yang melanggar.

- Penyebab lemah: lemahnya pengaturan mengenai penunjukan dan syarat-syarat mediator dalam mediasi perbankan, lemahnya pengaturan pelaksanaan dan penuangan hasil kesepakatan perdamaian dan pengaturan sanksi yang tidak tegas terhadap pihak yang tidak mematuhi isi kesepakatan mediasi perbankan.

\subsection{Saran}

Berdasarkan kesimpulan yang telah diuraikan diatas, maka saran yang dapat diberikan antara lain :

1. Keunggulan-keunggulan karakteristik yang dimiliki lembaga mediasi perbankan sebagai pilihan penyelesaian sengketa berpeluang menjadi pilihan penyelesaian perbankan terbaik, namun dalam penerapannya agar lebih mampu digali, dipahami dan dioptimalkan oleh pihak bank, nasabah yang bersengketa, dan termasuk juga oleh mediator dalam mediasi perbankan untuk dapat mengupayakan pelaksanaan penyelesaian sengketa secara tuntas tanpa meninggalkan dendam diantara para pihak.

2. Otoritas Jasa Keuangan sebagai pemegang otoritas tertinggi pengawasan perbankan Indonesia agar segera mengupayakan pembentukan lembaga mediasi perbankan independen oleh asosiasi perbankan dan melakukan penyempurnaan terhadap regulasi terkait mediasi perbankan yang dinilai berpotensi 
menghambat dan menyebabkan masih lemahnya tingkat penyelesaian sengketa melalui mediasi perbankan

\section{DAFTAR PUSTAKA}

\section{Buku}

Burhanuddin Abdullah, 2006, Jalan Menuju Stabilitas Mencapai Pembangunan Ekonomi Berkelanjutan, Pustaka LP3ES Indonesia, Jakarta.

Inosentius Samsul, 2009, Pengembangan Model Penyelesaian Sengketa Perbankan dalam Perpekstif Perlindungan Konsumen, Direktur Hukum Bank Indonesia, Jakarta.

Muhammad Djumhana, 2003. Hukum Perbankan di Indonesia, PT Citra, Bandung.

Rahmadi Usman,2011. Penyelesaian Pengaduan Nasabah dan Mediasi Perbankan, Bandar Maju, Bandung.

Susanti Adi Nugroho, 2008. Proses Penyelesaian Sengketa Konsumen Ditinjau dari Hukum Acara serta Kendala Implementasinya, Kencana, Jakarta.

Suyud Margono, 2000. ADR dan Arbitrase Proses Pelembagaan dan Aspek Hukum, Ghalia Indonesia, Jakarta.

\section{Artikel}

Bank Indonesia, Data Bank Indonesia terhadap Kasus-Kasus Perbankan melalui Mediasi, tercantum dalam URL : http://www.bi.go.id/web/id/, diakses tanggal 15 Maret 2016

Bank Indonesia, 2012, Data Penyelesaian Sengketa Melalui Mediasi Perbankan oleh Bank Indonesia, dikutip dari http://www.bi.go.id/web/id/, diakses pada 21 Maret 2016.

\section{Peraturan Perundang-Undangan}

Undang-Undang Nomor 10 tahun 1998 Tentang Perubahan Atas UndangUndang Nomor 7 Tahun 1992 Tentang Perbankan, Lembaran Negara Republik Indonesia Tahun 1998 Nomor 182 
Peraturan Bank Indonesia Nomor 7/7/PBI/2005 Tentang Penyelesaian

Pengaduan Nasabah, Lembaran Negara Republik Indonesia Tahun 2005 Nomor 17 DPNP/DPbs/DPBPR

Peraturan Bank Indonesia Nomor 10/10/PBI/2008 Tentang Perubahan Atas

Peraturan Bank Indonesia Nomor 7/7/PBI/2005 Tentang

Penyelesaian Pengaduan Nasabah, Lembaran Negara Republik Indonesia Tahun 2008 Nomor 38 DPNP/UKMI/DPbs/DKBU

Peraturan Bank Indonesia Nomor 8/5/PBI/2006 Tentang Mediasi

Perbankan, Lembaran Negara Republik Indonesia Tahun 2006 Nomor DPNP/DPbS/DPBPR

Peraturan Bank Indonesiia Nomor 10/1/PBI/2008 Tentang Perubahan Atas

Peraturan Bank Indonesia Nomor 8/5/PBI/2006 Tentang Mediasi

Perbankan, Lembaran Negara Republik Indonesia Tahun 2008 Nomor 10 DPN/DPbs/DPBR

Surat Edaran Mahkamah Agung No.8/14/DPNP Perihal Mediasi Perbankan 